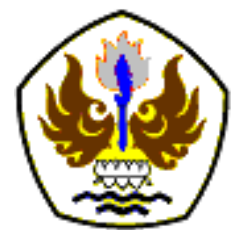

INFOMATEK

Volume 22 Nomor 2 Desember 2020

\title{
MERANCANG ALAT BANTU MEMBONGKAR DAN MEMASANG TROMOL REM PADA PROSES OVERHOUL SERVICE KENDARAAN TIPE BUS DAN TRUK BESAR
}

\author{
Ragil Pardiyono*, Rifan Saputra, Jahny Sastradiharja \\ Fakultas Teknologi Manufaktur \\ Universitas Jenderal Achmad Yani
}

\begin{abstract}
Abstrak: Penelitian ini bertujuan untuk merancang alat bantu mengurangi potensi sakit akibat kerja pada proses overhoul service penggantian kanvas rem kendaraan tipe bus dan truk besar. Metode perancangan alat bantu yang digunakan adalah metode rasional. Komponen alat bantu terpilih berdasarkan metode rasional diantaranya bentuk penampang adalah alas penampang berada di sisi kiri dan kanan dengan pelindung berada di sisi kiri dan kanan alas penampang. Bentuk rangka adalah bentuk kotak sebagai komponen rangka. Material penampang adalah baja karbon sedang. Bentuk pegangan tangan adalah elbow. Material bearing penampang adalah besi cor. Bentuk bearing penampang adalah ball bearing. Material rangka adalah besi hollow galvalume. Material baut roda adalah baja. Bentuk pengungkit adalah katrol. Bentuk baut pengungkit adalah baut hexagonal. Dimensi penampang adalah $50 \mathrm{~cm}$. Material pegangan tangan adalah stainless steel. Bentuk roda adalah dengan alas menggunakan besi. Material roda adalah besi. Material baut pengungkit baja. Bentuk baut roda adalalah baut hexagonal. Spesifikasi dimensi alat bantu mempunyai tinggi $170,05 \mathrm{~cm}$, lebar $43,11 \mathrm{~cm}$, tinggi pegangan tangan $134,375 \mathrm{~cm}$, panjang penampang $50 \mathrm{~cm}$. Alat bantu usulan dapat perubahan postur tubuh mekanik pada aktifitas melepas dan memasang pada level 1 yang menunjukkan aktifitas tersebut aman bagi operator.
\end{abstract}

Kata kunci: RULA, REBA, Sakit Akibat Kerja, Alat Bantu, Metode Rasional

\section{PENDAHULUAN}

PT. XYZ adalah perusahaan jasa otomotif. Salah satu layanannya adalah penggantian kanvas rem truk besar. Proses penggantian kanvas rem terdapat langkah kerja yang berpotensi menimbulkan sakit akibat kerja yaitu aktivitas melepas, mengangkat, meletakkan dan memasang tromol rem. Satu

\footnotetext{
*) ragil.pardiyono@lecture.unjani.ac.id
}

unit kendaraan truk besar terdiri dari 6 tromol dengan spesifikasi diameter $40 \mathrm{~cm}$ dan berat $51 \mathrm{~kg}$. Langkah kerja melepas, mengangkat, meletakkan dan memasang komponen tromol rem diuji dengan Rapid Upper Limb Assesment (RULA) dan Rapid Entire Body Assesment atau REBA untuk memastikan aktifitas tersebut berpotensi menimbulkan sakit akibat kerja atau tidak. Gambar aktifitas tersebut disajikan pada Gambar 1.

Pertama diterima: 8 November 2020

Direvisi: 13 November 2020

Disetujui untuk publikasi: 16 November 2020 
Berdasarkan perhitungan RULA untuk aktifitas melepas dan memasang tromol rem menghasilkan skor RULA grup A yaitu bagian tubuh lengan atas, lengan bawah dan pergelangan tangan adalah 6. Skor RULA grup B yaitu bagian punggung dan leher adalah 7 maka hasil rekapitulasi hasil penilaian total skor tabel $\mathrm{C}$ adalah 7 yang artinya level tindakan berada di level 4 menunjukkan bahwa kondisi ini berbahaya untuk segera dilakukan perbaikan untuk memperbaiki postur kerja dan mengurangi resiko kerja yang mengakibatkan sakit akibat kerja. Rekapitulasi perhitungan RULA aktivitas melepas tromol rem disajikan pada Tabel 1.

\begin{tabular}{|c|c|c|c|c|}
\hline Melepas & Mengangkat & Meletakkan & Memasang \\
\hline & & \\
\hline
\end{tabular}

\section{Gambar 1}

Aktivitas yang berpontensi menimbulkan sakit akibat kerja

Tabel 1. Rekapitulasi perhitungan RULA aktivitas melepas tromol rem

\begin{tabular}{|c|c|c|c|c|c|}
\hline \multirow[t]{2}{*}{ Grup } & \multirow[t]{2}{*}{ Bagian Tubuh } & \multicolumn{2}{|c|}{$\begin{array}{l}\text { aktivitas } \\
\text { melepas }\end{array}$} & \multicolumn{2}{|c|}{$\begin{array}{c}\text { aktivitas } \\
\text { memasang }\end{array}$} \\
\hline & & Sudut & Skor & Sudut & Skor \\
\hline \multirow{3}{*}{ A } & lengan atas & $97^{\circ}$ & 4 & 59 & 3 \\
\hline & lengan bawah & $62^{\circ}$ & 1 & 134 & 2 \\
\hline & $\begin{array}{l}\text { pergelangan } \\
\text { tangan }\end{array}$ & $31^{\circ}$ & 3 & 40 & 3 \\
\hline \multicolumn{2}{|r|}{ Total Skor } & \multicolumn{2}{|c|}{6} & \multicolumn{2}{|c|}{6} \\
\hline \multirow{2}{*}{ B } & punggung & $81^{\circ}$ & 4 & 61 & 4 \\
\hline & leher & $44^{\circ}$ & 3 & 10 & 1 \\
\hline \multicolumn{2}{|r|}{ Total Skor } & \multicolumn{2}{|c|}{7} & \multicolumn{2}{|c|}{7} \\
\hline $\mathrm{C}$ & Grand Score & \multicolumn{2}{|c|}{7} & \multicolumn{2}{|c|}{7} \\
\hline \multicolumn{2}{|l|}{ Level } & \multicolumn{2}{|c|}{4} & \multicolumn{2}{|c|}{4} \\
\hline \multicolumn{2}{|c|}{ Tindakan } & \multicolumn{2}{|c|}{$\begin{array}{c}\text { segera } \\
\text { dilakukan } \\
\text { perbaikan }\end{array}$} & \multicolumn{2}{|c|}{$\begin{array}{c}\text { segera } \\
\text { dilakukan } \\
\text { perbaikan }\end{array}$} \\
\hline
\end{tabular}

Perhitungan pada aktivitas mengangkat dan meletakkan tromol rem dihitung dengan REBA mempunyai skor grup A yaitu bagian tubuh punggung, leher dan kaki adalah 6. Skor REBA grup $B$ yaitu bagian tubuh lengan atas, lengan bawah dan pergelangan tangan adalah 4 maka hasil penilaian total skor tabel C adalah 8 yang artinya level tindakan berada di level 3 dengan level resiko tinggi. Maka harus segera dilakukan perbaikan untuk memperbaiki postur kerja dan mengurangi resiko kerja yang mengakibatkan sakit akibat kerja. Rekapitulasi perhitungan REBA aktivitas mengangkat dan meletakkan tromol rem disajikan pada Tabel 2. 
Tabel 2. Rekapitulasi perhitungan REBA aktivitas mengangkat dan meletakkan tromol rem

\begin{tabular}{|c|c|c|c|}
\hline Grup & Bagian Tubuh & Sudut $\left({ }^{\circ}\right)$ & Skor \\
\hline \multirow{3}{*}{ A } & punggung & 60 & 3 \\
\hline & leher & 38 & 2 \\
\hline & kaki & 34 & 1 \\
\hline & Total Skor & \multicolumn{2}{|c|}{6} \\
\hline \multirow{3}{*}{ B } & lengan atas & 42 & 2 \\
\hline & lengan bawah & 41 & 2 \\
\hline & $\begin{array}{l}\text { pergelangan } \\
\text { tangan }\end{array}$ & 47 & 2 \\
\hline & Total Skor & \multicolumn{2}{|c|}{7} \\
\hline $\mathrm{C}$ & Grand Score & \multicolumn{2}{|c|}{8} \\
\hline Level & & \multicolumn{2}{|c|}{3} \\
\hline \multicolumn{2}{|c|}{ Tindakan } & \multicolumn{2}{|c|}{$\begin{array}{c}\text { segera dilakukan } \\
\text { perbaikan }\end{array}$} \\
\hline
\end{tabular}

Bedasarkan pengamatan dan analisis RULA dan REBA dapat disimpulkan bahwa postur kerja mekanik ketika aktivitas melepas, mengangkat, meletakkan dan memasang tromol rem akan menimbulkan resiko terjadinya keluhan pada bagian tubuh mekanik. Hal itu juga di buktikan aturan dari Worksafe Australia (Gun [1]) tentang batas normal beban angkat suatu material. Jika beban angkat lebih kecil dari $16 \mathrm{~kg}$, maka tidak perlu diperlakukan khusus. Jika beban angkat antara $16 \mathrm{~kg}$ sampai dengan $25 \mathrm{~kg}$, maka perlu diperhatikan dalam metode pengangkatannya. Jika beban angkat antara $25 \mathrm{~kg}$ sampai dengan $34 \mathrm{~kg}$, maka perlu diperhatikan dalam metode pengangkatannya dan intesitasnya. Jika beban kerja angkat di atas $34 \mathrm{~kg}$, maka harus dibantu dengan peralatan mekanis. Berdasarkan permasalahan di atas maka tujuan penelitian adalah merancang alat bantu beserta komponen penyusunnya, untuk memperbaiki postur kerja mekanik pada saat melakukan aktivitas melepas, mengangkat, meletakkan dan memasang tromol rem. Tujuan perancangan ini adalah untuk mendapatkan komponen penyusun alat bantu.

\section{METODOLOGI}

Menurut Dockrell et.al [2] Rapid Upper Limb Assessment (RULA) merupakan metode observasi cepat untuk analisis postur tubuh. RULA adalah metode observasi subjektif dari analisis postur tubuh yang berfokus pada tubuh bagian atas, tetapi mencakup tubuh bagian bawah. Menurut Hignett, S., \& Mc Atamney, L. [3] REBA dikembangkan untuk memenuhi kebutuhan untuk menganalisis terhadap jenis postur kerja untuk mengetahui resiko sakit.

Metode rasional dipergunakan untuk penelitian mengenai perancangan produk atau alat. Metode sangat sistematis pada setiap tahapnya supaya peroleh hasil yang maksimal. Tahapan metode rasional terdiri dari; klarifikasi tujuan, penetapan fungsi, penetapan spesifikasi, penentuan karakteristik, pembangkitan alternatif, evaluasi alternatif, arsitektur sistem, perancangan konfigurasi, perancangan parametrik, dan perancangan detail (Pardiyono \& Zairda [4]).

\section{ANALISIS DAN PEMBAHASAN}

Kebutuhan sistem dan pengguna diklarifikasi menjadi tujuan perancangan alat. Metode 
yang digunakan adalah pohon tujuan yaitu suatu metoda yang menguraikan kebutuhan sistem dan pengguna yang diperoleh menjadi hubungan tujuan dari sub tujuan dan menjelaskan hubungan yang terjadi antara keduanya (Ulrich \& Eppinger [5]). Pohon tujuan penelitian ini disajikan pada Gambar 2.

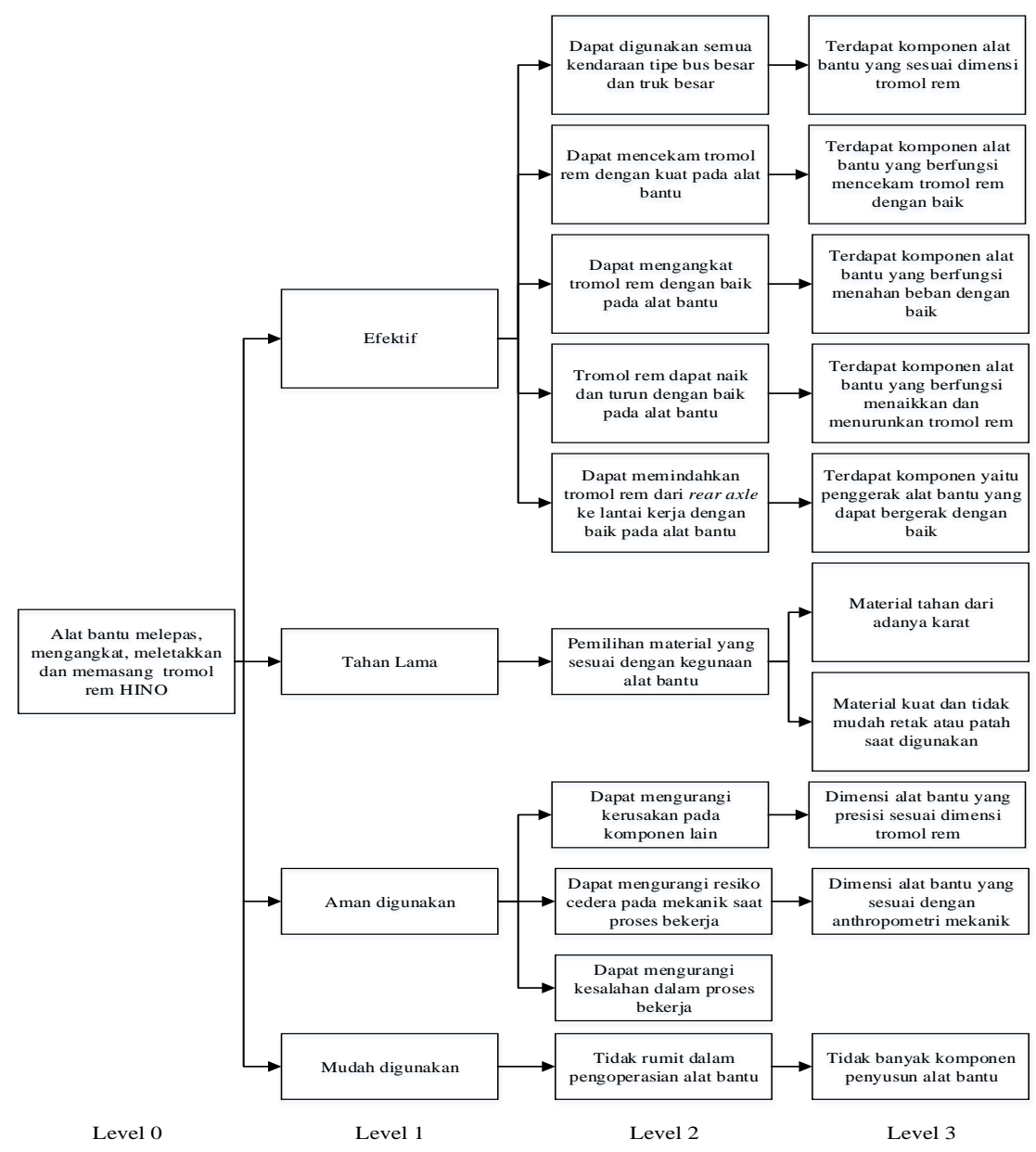

Gambar 2

Pohon Tujuan.

Dari Gambar 2 dapat dilihat pohon tujuan memiliki 3 level. Level 0 sebagai tujuan dari penelitian ini. Level 1 sebagai fungsi dari penelitian. Level 2 sebagai atribut (bahasa konsumen). Level 3 sebagai spesifikasi (bahasa engineer). Penetapan fungsi dilakukan untuk menetapkan batasan rancangan alat. Penetapan fungsi dapat menggunakan metode analisis fungsional.

\subsection{Penetapan Fungsi}

Tahap penetapan fungsi merupakan aliran proses yang berkaitan dengan pencapaian tujuan perancangan yang telah ditetapkan 
Merancang Alat Bantu Membongkar dan Memasang Tromol Rem pada Proses Overhoul Service Kendaraan Tipe Bus dan Truk Besar

fungsi yang harus terpenuhi oleh alat bantu melepas, mengangkat, meletakkan dan memasang tromol rem. Alat yang digunakan adalah Black Box (Gambar 3) dan Transparant

Box (Gambar 4).
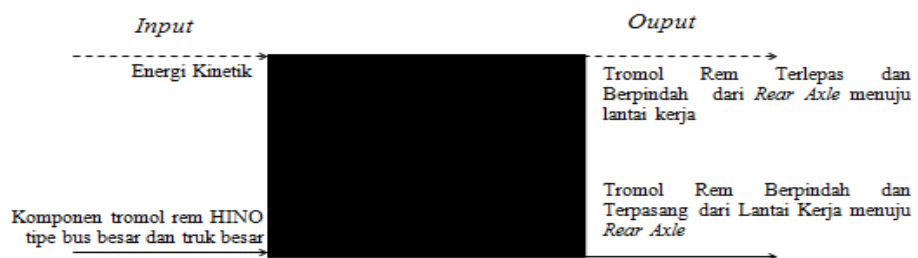

Gambar 3

Black Box

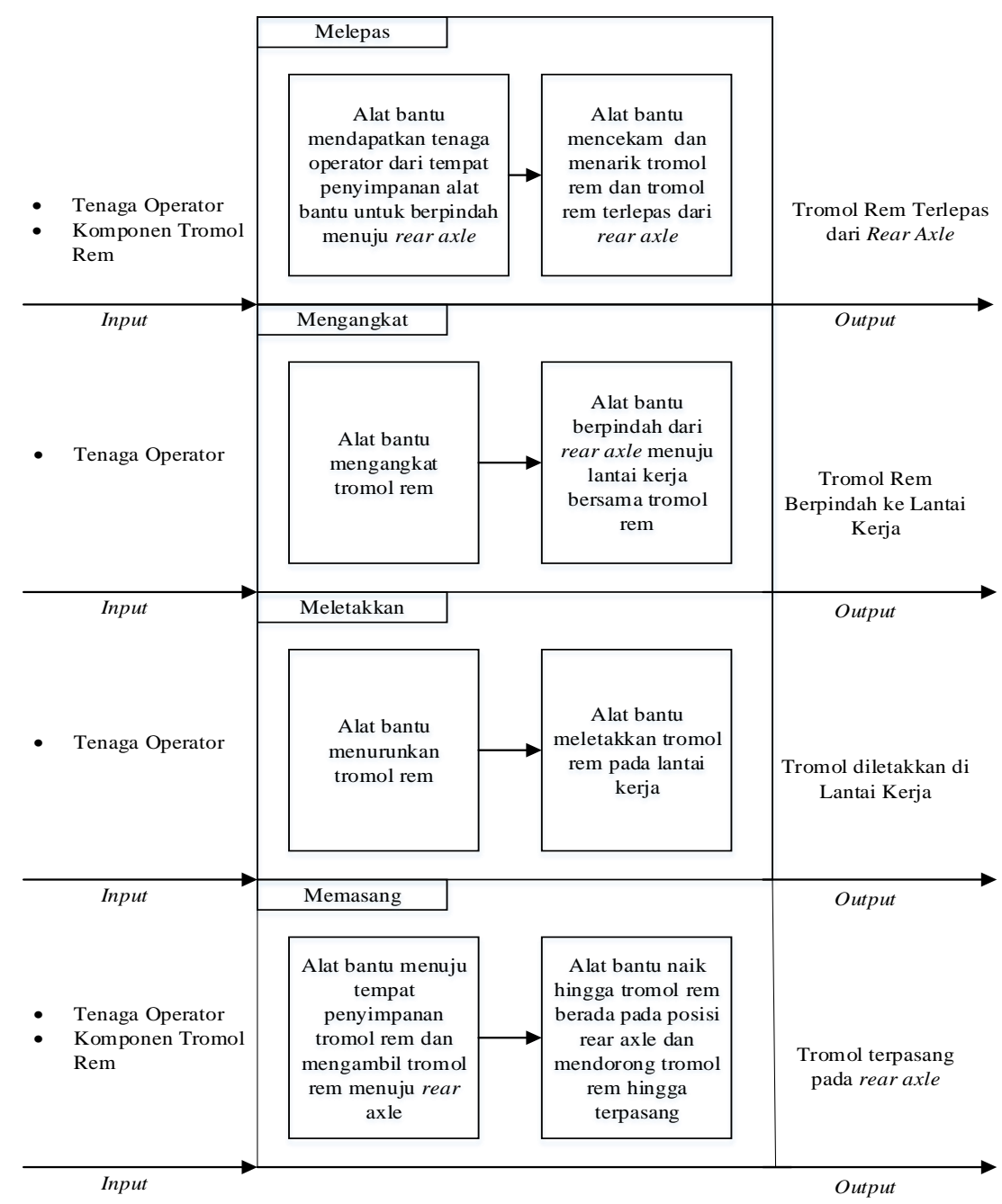

Gambar 4

Transparant Box. 


\subsection{Penetapan Spesifikasi Performansi}

Atribut performansi diturunkan dari fungsi dan tujuan perancangan, sehingga pohon tujuan pun dapat menjadi acuannya. Dari ketentuan tersebut maka yang menjadi karakteristik teknik dari alat bantu adalah level terakhir dari pohon tujuan (Ginting et al [7]). Spesifikasi performansi yang dibutuhkan dalam penyelesaian perancangan alat bantu ini adalah:

1. Bisa mencekam, melepas, mengangkat, memindahkan, meletakkan serta memasang tromol rem dengan presisi.

2. Bisa berpindah tempat dari rear axle menuju lantai kerja atau sebaliknya dengan baik.

3. Dapat menahan maksimal $100 \mathrm{~kg}$

4. Dapat digunakan untuk benda berdiamter maksimal $50 \mathrm{~cm}$

5. Alat bantu tahan dari adanya karat dengan masa pakai yang relatif lama

6. Tidak mudah retak atau patah saat digunakan karena rangka terbuat dari besi

7. Dapat mengurangi kerusakan komponen lain saat digunakan.

8. Dapat mengurangi resiko cedera pada punggung dan jari tangan saat bekerja.

9. Dapat menggantikan tenaga operator saat mengangkat tromol rem sehingga mengurangi kesalahan dalam bekerja.

10.Dapat digunakan semua operator karena disesuaikankan dengan postur tubuh

11.Pengoperasiannya tidak rumit

\subsection{Penentuan Karakteristik Teknik}

Menentukan atribut di dasarkan pada hasil kebutuhan pengguna (mekanik). Atribut-atribut tersebut memiliki karakteristik masing-masing yang nantinya akan dihubungkan satu sama lain antar karakteristik teknik. Metode yang digunakan House of Quality adalah bagan yang menampilkan hubungan antara suara konsumen dan karakteristik teknisnya (Madu [6]). House of Quality dalam tahap ini disajikan pada tabel 3. Selanjutnya menghitung nilai dari tingkat kolerasi absolut (TKA) dengan perhitungan TKA $=\Sigma$ (nilai kolerasi $x$ bobot \%). Rekapitulasi tingkat korelasi absolut yang memiliki bobot nilai tertinggi dapat dilihat pada Tabel 4 di bawah ini.

Tabel 4 Urutan Karakteristik Teknik

\begin{tabular}{cll}
\hline No & \multicolumn{1}{|c}{ Karakteristik Teknik } & Nilai \\
& TKA \\
\hline 1 & Bentuk penampang & 7,12 \\
\hline 2 & Bentuk rangka & 6,99 \\
\hline 3 & Material penampang & 5,34 \\
\hline 4 & Bentuk pegangan tangan & 4,43 \\
\hline 5 & Material bearing penampang & 3,49 \\
\hline 6 & Bentuk bearing penampang & 3,45 \\
\hline 7 & Material rangka & 3,44 \\
\hline 8 & Material baut roda & 3,44 \\
\hline 9 & Bentuk pengungkit & 2,94 \\
\hline 10 & Bentuk baut pengungkit & 2,94 \\
\hline 11 & Dimensi penampang & 2,51 \\
\hline 12 & Material pegangan tangan & 2,33 \\
\hline 13 & Bentuk roda & 2,22 \\
\hline 14 & Material roda & 2,22 \\
\hline 15 & Material baut pengungkit & 2,22 \\
\hline 16 & Bentuk baut roda & 2,16 \\
\hline &
\end{tabular}


Merancang Alat Bantu Membongkar dan Memasang Tromol Rem pada Proses Overhoul Service Kendaraan Tipe Bus dan Truk Besar

Tabel 3

House Of Quality

\begin{tabular}{|c|c|c|c|c|c|c|c|c|c|c|c|c|c|c|c|c|c|}
\hline & 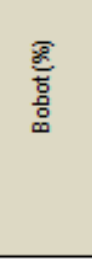 & 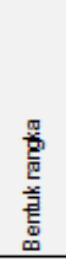 & 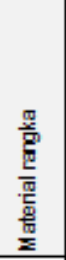 & 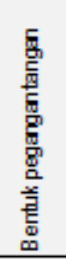 & 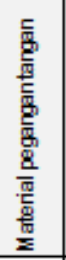 & 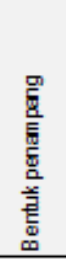 & 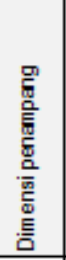 & 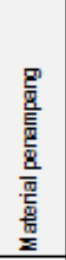 & 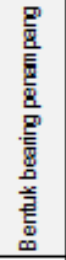 & 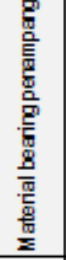 & 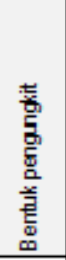 & 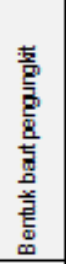 & 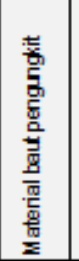 & 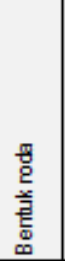 & 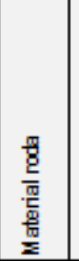 & 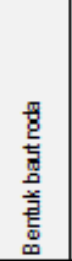 & 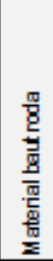 \\
\hline $\begin{array}{l}\text { Terdapat komponen alat banth yang } \\
\text { berfingsimenahan bebandengan bak }\end{array}$ & $16,67 \%$ & 9 & 9 & 3 & 3 & 9 & 1 & 9 & 3 & 9 & 1 & 1 & 3 & 3 & 3 & 1 & 9 \\
\hline $\begin{array}{l}\text { Dimensi alst banth yang sesua } \\
\text { dengan anthropometri mekank }\end{array}$ & $16,67 \%$ & 9 & 1 & 9 & 3 & 3 & 1 & 1 & 1 & 1 & 1 & 1 & 1 & 1 & 1 & 1 & 1 \\
\hline $\begin{array}{l}\text { Dimensi alst banth yang pressis sesua } \\
\text { dimensi tromd rem }\end{array}$ & $13,38 \%$ & 3 & 1 & 3 & 1 & 9 & 9 & 9 & 9 & 3 & 1 & 1 & 1 & 1 & 1 & 1 & 1 \\
\hline $\begin{array}{l}\text { Terdapat komponen alat banth yang } \\
\text { beriungsi mencokam tromd rem } \\
\text { dengan bak }\end{array}$ & $11,11 \%$ & 9 & 1 & 3 & 1 & 9 & 3 & 9 & 1 & 1 & 1 & 1 & 1 & 1 & 1 & 1 & 1 \\
\hline $\begin{array}{l}\text { Terdapat komponen alat banth yang } \\
\text { berfingsimen akkan dan mendrukkan } \\
\text { tromol rem }\end{array}$ & $11,11 \%$ & 3 & 3 & 3 & 1 & 9 & 3 & 9 & 1 & 1 & 9 & 9 & 3 & 1 & 1 & 1 & 3 \\
\hline $\begin{array}{l}\text { Terd apat komponen yatu, penggerak } \\
\text { alat banti yang dapat bergerak dengan } \\
\text { baik }\end{array}$ & $11,11 \%$ & 9 & 3 & 1 & 1 & 3 & 1 & 1 & 1 & 3 & 1 & 1 & 1 & 9 & 3 & 3 & 3 \\
\hline $\begin{array}{l}\text { Tidak banyak komponen penyusun alat } \\
\text { bants }\end{array}$ & $11,11 \%$ & 9 & 1 & 9 & 1 & 9 & 1 & 1 & 9 & 1 & 9 & 9 & 1 & 1 & 1 & 9 & 1 \\
\hline $\begin{array}{l}\text { Material kuat dan fdak mudah retak } \\
\text { atau patah saat dgunakan }\end{array}$ & $5,56 \%$ & 3 & 9 & 3 & 9 & 9 & 1 & 3 & 3 & 9 & 3 & 3 & 9 & 1 & 9 & 1 & 9 \\
\hline Material tahan dari adanya karat & $2,78 \%$ & 3 & 9 & 3 & 9 & 3 & 1 & 3 & 3 & 9 & 3 & 3 & 9 & 1 & 9 & 3 & 9 \\
\hline \multicolumn{2}{|l|}{ Total Bobot } & 6,99 & 3,44 & 4,43 & 2,33 & 7,12 & 2,51 & 5,34 & 3,45 & 3,49 & 2,94 & 2,94 & 2,22 & 2,22 & 2,22 & 2,16 & 3,44 \\
\hline
\end{tabular}

\subsection{Pembangkitan Alternatif}

Peta morfologi menampilkan semua komponen produk rancangan beserta alternatif-alternatif yang telah dikembangkan untuk menentukan alternatif yang terpilih. (Pardiyono \& Zairda [4]). Pemilihan alternatif dilakukan dengan pertimbangan-pertimbangan rasional terhadap kebutuhan dan keterbatasan sistem yang ada dalam proses perancangan. Pembangkitan alternatif menggunakan
Morphological chart yang berisi elemenelemen komponen, atau sub solusi lengkap.

\subsection{Evaluasi Alternatif}

Evaluasi alternatif merupakan suatu proses penentuan alternatif terbaik dari berbagai macam alternatif yang muncul, sehingga diperoleh suatu rancangan yang baik dan dapat memenuhi keinginan konsumen. Rekapitulasi alternatif terpilih untuk setiap karakteristik teknik dapat dilihat pada Tabel 4. 
Tabel 4 Rekapitulasi Alternatif Terpilih

\begin{tabular}{|c|c|c|c|c|}
\hline No & Karakteristik Teknik & Alternatif 1 & Alternatif 2 & Alternatif 3 \\
\hline 1 & Bentuk penampang & & & \\
\hline 2 & Bentuk rangka & & & \\
\hline 3 & Material penampang & Baja karbon rendah & edang & $\begin{array}{c}\text { Baja karbon } \\
\text { tinggi }\end{array}$ \\
\hline 4 & Bentuk pegangan tangan & & & \\
\hline 5 & Material bearing penampang & Alumunium & & Teflon \\
\hline 6 & Bentuk bearing penampang & & & \\
\hline 7 & Material rangka & $\begin{array}{c}\text { Besi Hollow } \\
\text { Galvanise }\end{array}$ & $\begin{array}{l}\text { Resi Hollow } \\
\text { Galvalumn }\end{array}$ & Plat Besi \\
\hline 8 & Material baut roda & Kuningan & Besi & 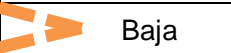 \\
\hline 9 & Bentuk pengungkit & & & \\
\hline 10 & Bentuk baut pengungkit & & & \\
\hline 11 & Dimensi penampang & $30 \mathrm{~cm}$ & $40 \mathrm{~cm}$ & \\
\hline 12 & Material pegangan tangan & Alumunium & Stainle s Steel & Teflon \\
\hline 13 & Bentuk roda & & & \\
\hline 14 & Material roda & Karet & Besi & Nylon \\
\hline 15 & Material baut pengungkit & Kuningan & Besi $=$ & 0 \\
\hline 16 & Bentuk baut roda & & & \\
\hline
\end{tabular}

\subsection{Perancangan Perakitan}

Perancangan perakitan merupakan langkah menyusun suatu rancangan alat yang sesuai dengan keinginan pengguna. Struktur rancangan produk dan material yang digunakan dibuat struktur Bill of Material yang dapat dilihat pada Gambar 5. 
Merancang Alat Bantu Membongkar dan Memasang Tromol Rem pada Proses Overhoul Service Kendaraan Tipe Bus dan Truk Besar

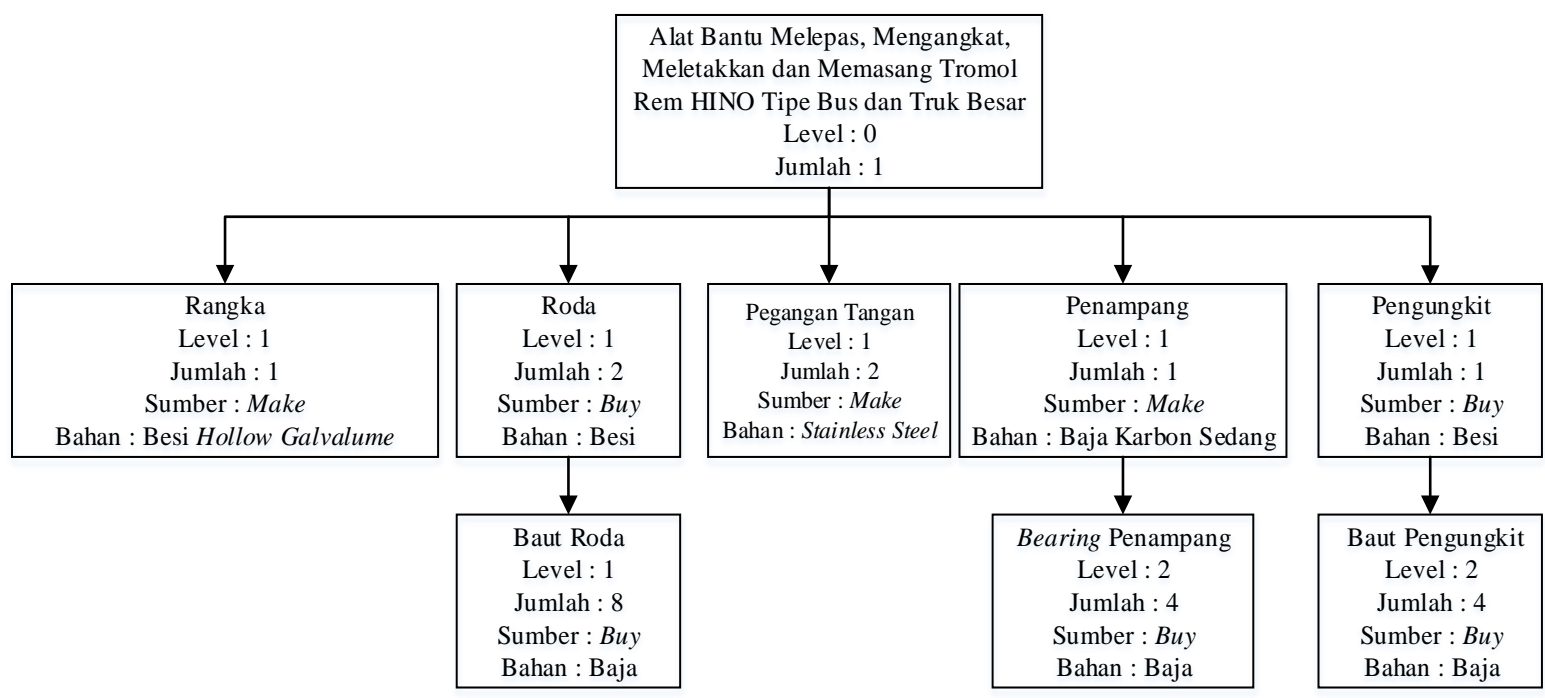

Gambar 5

Bill of Material Alat bantu

\subsection{Perancangan Parametrik}

Perancangan Parametrik adalah melakukan penghitungan dimensi-dimensi alat bantu (Geren et al [8]). Data anthropometri yang menjadi dasar penentuan dimensi alat bantu adalah Tinggi Tubuh Posisi Berdiri Tegak (Rangka), Tinggi Bahu Berdiri (Pegangan Tangan), Lebar Bahu Berdiri (Rangka). Desain alat bantu terbaik bedasarkan keinginan pengguna. Spesifikasi dimensi alat bantu mempunyai tinggi $170,05 \mathrm{~cm}$, lebar $43,11 \mathrm{~cm}$, tinggi pegangan tangan $134,375 \mathrm{~cm}$, panjang penampang $50 \mathrm{~cm}$. Berikut desain terbaik bedasarkan keinginan pengguna dan data anthropometri disajikan pada Gambar 6 dan 7.

Berdasarkan perhitungan skor RULA dan REBA sistem kerja usulan dibandingkan dengan sistem kerja awal terdapat perubahan postur tubuh mekanik. Aktifitas melepas dan memasang tromol rem menghasilkan skor 1 . Skor RULA bagian punggung dan leher adalah 1 maka total skor adalah 1 yang artinya level tindakan berada di level 1 menunjukkan bahwa kondisi ini aman bagi operator. 


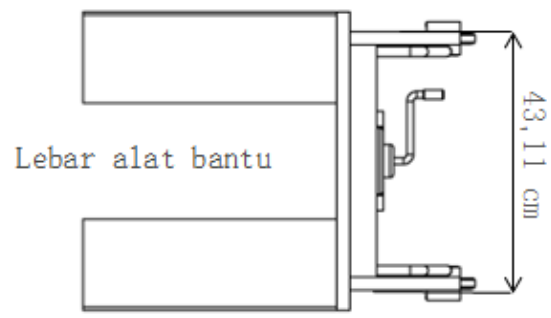

Tinggi alat bantu
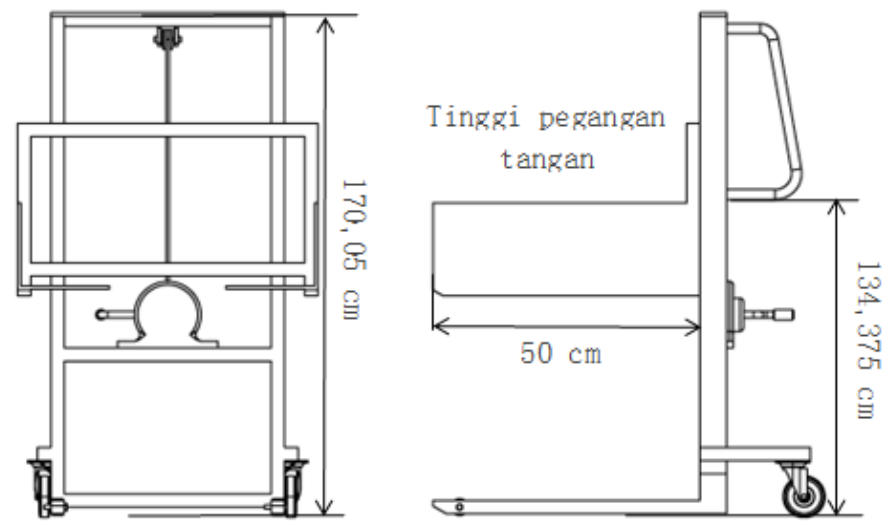

Gambar 6

Gambar Teknik Alat bantu

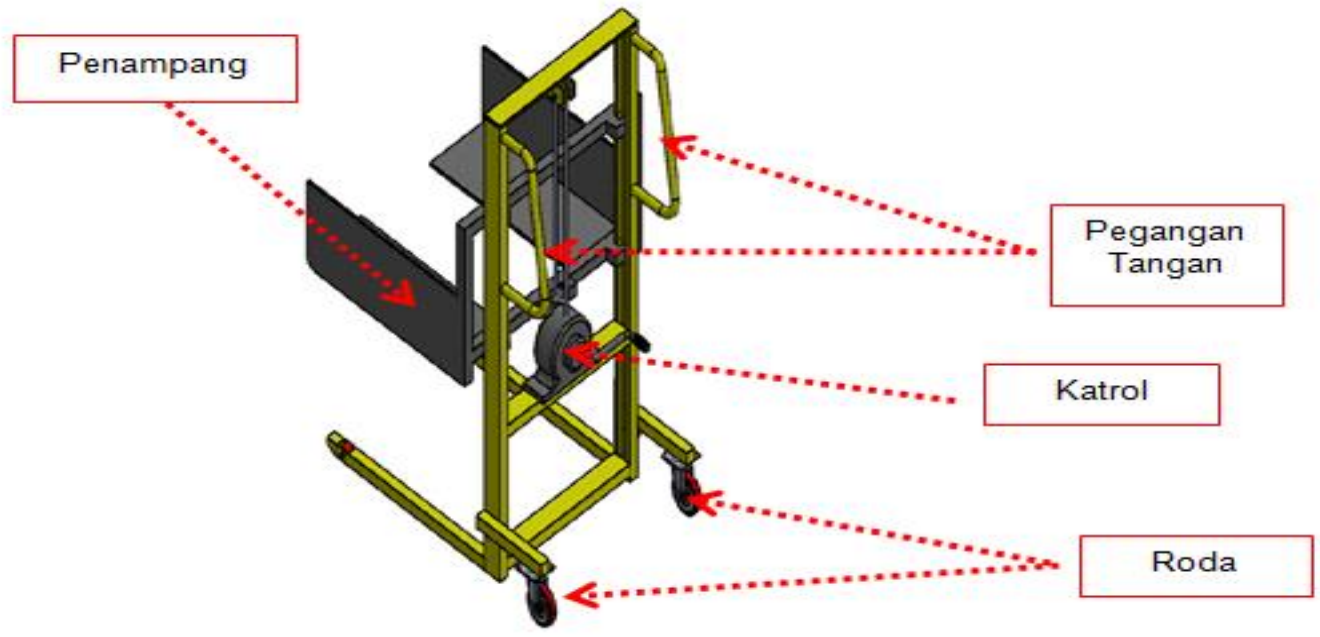

Gambar 7

Gambar 3D alat bantu 


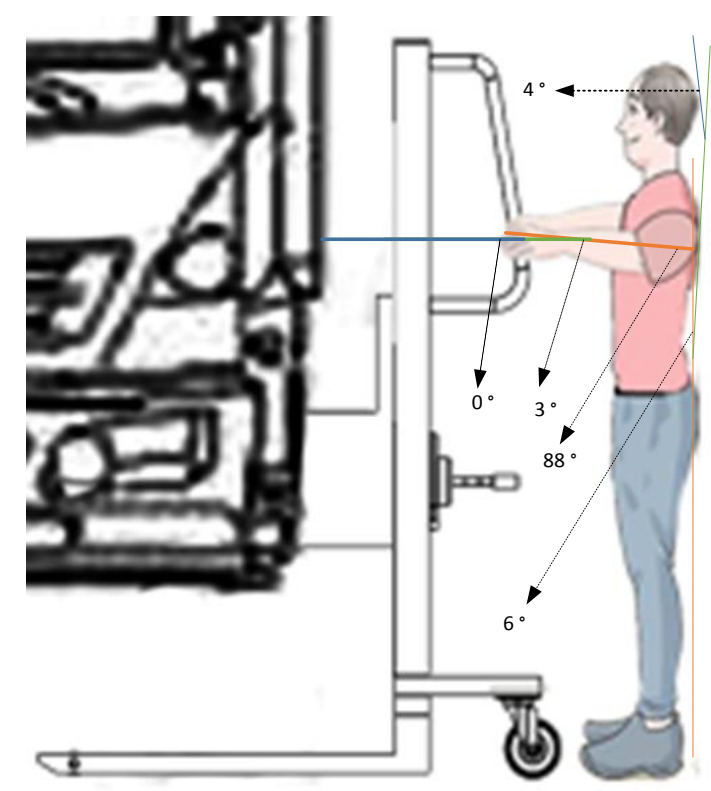

\section{Gambar 8}

Aktivitas melepas tromol rem

\section{KESIMPULAN}

Berdasarkan hasil pengolahan data dan analisis dapat disimpulkan bahwa alat bantu hasil rancangan dapat menurunkan mengurangi resiko sakit akibat kerja dari level bahaya ke level aman. Komponen penyusun alat bantu yaitu komoponen penampang untuk menahan tromol rem agar tidak bergerak, komponen rangka untuk menopang alat bantu, katrol untuk mengangkat tromos rem dan roda untuk pergerakan alat bantu. Spesifikasi dimensi alat bantu mempunyai tinggi 170,05 $\mathrm{cm}$, lebar $43,11 \mathrm{~cm}$, tinggi pegangan tangan $134,375 \mathrm{~cm}$, panjang penampang $50 \mathrm{~cm}$.

\section{DAFTAR PUSTAKA}

[1] Gun, R. T. (1990). Worksafe Australia: to the McKay report and beyond. Community health studies, 14(1), 65-72.

[2] Dockrell, S., O'Grady, E., Bennett, K., Mullarkey, C., Mc Connell, R., Ruddy, R., \& Flannery, C. (2012). An investigation of the reliability of Rapid Upper Limb Assessment (RULA) as a method of assessment of children's computing posture. Applied ergonomics, 43(3), 632636.

[3] Hignett, S., \& McAtamney, L. (2000). Rapid entire body assessment (REBA). Applied ergonomics, 31(2), 201-205.

[4] Pardiyono, R., \& Zairda, C. I. E. (2020). Perancangan Alat Bantu Pemindahan 
Brake Cylinder di Departemen Sarana Kereta Api PT. Pindad PT. Pindad (PERSERO). Infomatek: Jurnal Informatika, Manajemen dan Teknologi, 22(1), 1-14.

[5] Ulrich, K. T. (2003). Product design and development. Tata McGraw-Hill Education.

[6] Madu, C. N. (2006). House of Quality (QFD) in a Minute. Chi Publishers Inc.

[7] Ginting, R., Batubara, T. Y., \& Widodo, W. (2017). Desain Ulang Produk Tempat
Tissue Multifungsi Dengan Menggunakan Metode Quality Function Deployment. Jurnal Sistem Teknik Industri, 19(2), 1-9.

[8] Geren, N., Akçalı, O. O., \& Bayramoğlu, M. (2017). Parametric design of automotive ball joint based on variable design methodology using knowledge and feature-based computer assisted 3D modelling. Engineering Applications of Artificial Intelligence, 66, 87-103. 